\title{
ABATEMENT OF CRIMINAL LITIGATION IN DISSOLUTION BY MERGER:
}

\section{A MODERN ANACHRONISM*}

IT IS a maxim of the common law that all litigation to which a corporation is a party abates on dissolution. ${ }^{2}$ Although the doctrine is said to rest on the analogy between corporate and natural persons, ${ }^{2}$ it was apparently extended at old common law, somewhat anomalously, to apply to some causes of action which, if brought against an individual, would survive death. ${ }^{3}$

* United States v. Line Material Co., 202 F.2d 929 (6th Cir. 1953).

$12 \mathrm{KYD}$, LAW OF CORPORATIONS, 516 (1794). This rule evolved in a time when all corporations were municipal, ecclesiastical, or eleemosynary, and business corporations were unknown. See Marcus, Suability of Dissolved Corporations, 58 HARv. L. REV. 675, 678 (1945). "Practically, it has never been applied, in England, to insolvent or dissolved moneyed corporations. ..." ANGELL \& AMEs, Corporations $\S 779 \mathrm{a}$ ( $\mathrm{I}$ Ith ed. I882), and it has been doubted whether the rule ever existed in New York. See Shayne v. Evening Post Publishing Co., r68 N.Y. 70, 76, 61 N.E. I I 5, I I6 (IgOI). Many courts in the United States have stated this to be the common law rule, without too deep an inquiry into its origin or soundness, e.g., United States v. Alexander, 24 Fed. Cas. 769, No. 14,428 (D.C. Cir. 1833); cf. Broughton v. Pennsacola, 93 U.S. $266(1876)$; and cases cited Note, 47 A.L.R. 1288, 1353 ff. (1927). Coincident with the extinguishment of liability, actions by or against the corporation were also abated. Id. at $1380 \mathrm{ff}$. and cases cited therein. But again such a doctrine was the result of uncritical analogy with non-business corporations.

${ }_{2}$ I AM. JUR. $\S 52$ at p. 55 (1936); I C.J.S. $\S 102$ at p. I40 (1936); 16 Fretcher, Cyclopedia Corporations $\$ 8$ I 39 (Rev. vol. r 942) (stating that cven at common law many actions survived). And see, e.g., Oklahoma Natural Gas Company v. Oklahoma, 273 U.S. 257,259 (1927) (dissolution occurring under statutes silent as to continuance of the existence of dissolved corporations for purposes of suit), citing inter alia, Mumma v. Potomac Company, 8 Pet. 28I (U.S. I834). Also see Chicago Title Co. v. Wilcox Bldg. Corp., 302 U.S. 120 (1937); Defense Supplies Corp. v. Lawrence Warehouse Co., 336 U.S. 63 I (1949).

${ }^{3}$ At common law, apparently no criminal actions against individuals survived death. See Schreiber v. Sharpless, i io U.S. 76, 86 (I884), nor did most causes based on tort, Prosser, TORTS $\S$ IO3 (I94I). But where the tortfeasor benefited by his act, the action survived against the executor, Hambly v. Trott, I Cowp. 37x, 98 Eng. Rep. I136 (1776); and most causes based on contract survived, 6 WILLISTON, CONTRACTS \& I 945 (Rev. ed. r 938 ).

Because of the non-business nature of the old common law corporations, however, upon dissolution personalty may have escheated to the King, (No clear authority for escheat can be found, although text writers and some cases consistently refer to the escheat as established practice. Kyd stated that "What becomes of the personal estatc is, perhaps, not decided; but probably it vests in the crown." $2 \mathrm{KX \textrm {D }}$, op. cit., supra 
Application of this doctrine, however, has not been rigid. It has been judicially tempered through the years to permit the satisfaction of civil claims against a dissolved corporation out of the assets of its liquidating estate ${ }^{4}$ and even its stockholder distributees, ${ }^{5}$ particularly in a merger situation. ${ }^{6}$ But, apparently, no suggestion is found in the common law that penal actions may survive corporate dissolution. ${ }^{7}$ In addition, today, most states have enacted statutes conferring on a corporation the capacity to sue and be sued for a specified period of time after dissolution ${ }^{8}$ or merger; ${ }^{9}$ but these statutes have not been commonly interpreted to comprehend criminal litigation. ${ }^{10}$

note 6 , at 516 ) and the realty reverted to the donors. I BL. Comm. $*_{4} 84$. Evidently, not even contract actions or "benefiting" tort actions survived corporate dissolution. See I BL. CoMm. $*_{4} 84$.

' See Note, 47 A.L.R. I288, 1355 ff. (1927).

- Marcus, supra note 1 , at 680 , citing 8 Thompson, Corporations $\$ 6522$ (3d ed. 1927). Also see Note, I5 A.L.R. III2, III4 ff. (I92I).

- 5 Fletcher, Cyclopedia Corporations $\$ 7180$ (Rev. vol. 1938); Note, 89 Am. St. Rep. 604, 648 (1903).

7 I AM. Jur. $\$ 54$ at p. 58 (1936). In United States v. Leche, 44 F. Supp. 765 (E.D. La. 1942), the court granted a motion to abate indictment on the ground that the corporation had dissolved under Texas law. While referring to the Texas statutes to determine corporate existence, the court, somewhat surprisingly, held that the question on the motion for abatement must be determined without respect to the Texas statute which would have continued the liability of the corporation in this instance, inasmuch as an infraction of federal law was involved. In the absence of an applicable federal statute, the court reasoned that it must reach its decision in accordance with the principles of common law existing prior to the Declaration of Independence, Id. at 766. Such reasoning, if not the result, is contra to the rationale in United States v. Safeway Stores, Inc., 140 F.2d 834 (roth $\mathrm{Cir}$. 1944), and the present case. See also Funk v. United States, 290 U.S. 371, 383 (1933); Rosen v. United States, 245 U.S. $467,470-472$ (1917); D'Oench, Duhme \& Co. v. F.D.I.C., 3 I 5 U.S. 447, 465475 (194I).

${ }^{8}$ Continuance of the corporation for purposes of suit is usually set out in the "winding up" sections of the statute. E.g., CAL. CORP. C.A. \$ 5400 (1953); Fla. STAT. ANN. $\$ \$ 610.18,611.32,612.47$ (1944); MAss. ANN. LAWS c. 155, 551 (1948); N.J. Stat. ANN. tit. 14, \& 14:13-4 (1939); N.Y. Gen. CoRP. LAW \& 29 (1943) and N.Y. Stock CoRp. Law $\S$ I0 $_{5}(8)$ (I95I); N.C. Gen. Stat. $\$$ 55-132 (1950); Wis. STAT. $\$$ I 81.02 (1947).

${ }^{\circ}$ E.g., Cal. CoRP. C.A. $\$ 4116$ (I953); Fla. Stat. ANn. $\$ 612.41$ (1944); Mass. ANN. Laws, c. $156, \$ 46 \mathrm{c}(1948)$; N.J. STAt. ANN. tit. 14, $\$ 14: 12-5$ (1939); N.Y. STOCK CoRP. LAW $\$ \$ 90,9 I(6)$ (I95I); N.C. Gen. STAT. $\$$ 55-I68 (1950); W1s. Stat. $\$$ I $81.06(8 \mathrm{c})$ (1947).

${ }_{10}$ United States v. Safeway Stores, Inc., I40 F.2d 834 (Ioth Cir. I944); United States v. Borden Co., 28 F. Supp. 177 (N.D. I1l. 1939). In the Safeway case defendant corporation made a bona fide dissolution shortly before the return of an indictment under the Sherman Act. The court found that none of the statutes of the states involved provided for the survival of criminal actions. As a matter of fact, after the Safeway "dissolution" a "new" corporation carried on the business with 
Whether criminal litigation survives a corporate merger was recently considered in United States v. Line Material Company. ${ }^{11}$ Line Material and two other corporations were alleged to have engaged in monopolistic and restrictive practices in the manufacture and sale of street lighting equipment in the United States. ${ }^{12}$ After having been indicted for alleged violation of sections one and two of the Sherman Anti-trust Act, ${ }^{13}$ the defendant, a Delaware corporation, vertically merged in good faith with another corporation. The indictment was dismissed. The Circuit Court of Appeals for the Sixth Circuit, after making the usual finding that at common law all litigation to which a corporation is a party abates upon dissolution, ${ }^{14}$ affirmed ${ }^{15}$ on the ground that the law of the state of incorporation made no provision for survival of criminal litigation after corporate dissolution by merger.

Section 42 of the Delaware Corporation Law provides that dissolved corporations shall be continued for three years "for the purpose of prosecuting and defending suits by or against them, and of enabling them gradually to settle and close their business ... provided, however, that with respect to any action, suit or proceeding" commenced prior to

the same name, property, stockholders, etc. Marcus, supra note I at 704 .

In the Borden case defendant corporations executed a bona fide merger approximately two and a half years before an indictment was returned under the Sherman Act; thereafter, the merged corporation sold out and dissolved. The court construed section 60 of the Delaware Corporation Law to abate the criminal action. (It is interesting to note that, although the court put the abatement on the ground of the earlier merger, in fact the corporation later "truly" dissolved before abatement was pleaded.)

${ }^{11} 202$ F.2d 929 (6th Cir. 1953).

12 Transcript of Record, p. 9. United States v. Line Material Co., ibid.

${ }^{13} 26$ STAT. $209(1890)$, as amended, 50 STAT. 693 (1937), 15 U.S.C. $\$ \S$ I \& 2 (1946).

${ }^{14}$ But cf. Windhurst v. Central Leather Co., 105 N.J. Eq. 621,149 Atl. 36 (1930) (merger of two corporations not equivalent to statutory dissolution). Presumably, a federal criminal statute expressly providing for prosecution of state-dissolved corporations would prevail over state law. Cf. Northern Securities Co. v. United States, I93 U.S. $197,346\left(\mathrm{x}_{904}\right)$. The fact that a statute imposes a liability in the nature of a penalty has not always been regarded as decisive against its survival. Cf. Union Market Nat'l Bank v. Gardiner, 276 Mass. 490, I77 N.E. 682, 79 A.L.R. I512 (I931). In a merger situation see Miller Management Co. v. State, 140 Tex. 370, 167 S.W. $2 d$ 728 (r943) (Under Tennessee statute the corporation continued in existence, for purposes of defending and disposiug of suit brought by the state of Texas for recovery of penalties for transaction of intra-state business in Texas without a permit.). Cf. Terry Packing v. Southern Exp. Co., 143 S.C. 1 , I4I S.E. I44 (1927) (Consolidated express company organized under Director General held liable for statutory penalties due from one of the consolidated companies.).

${ }^{18}$ Although significant differences are apparent between "true" dissolution, and dissolution by merger, the court in the present case based its decision on the rensoning in the Safeway and Borden cases, discussed supra note ro. 
or within three years after dissolution, they shall be continued beyond the three year period. ${ }^{\mathbf{1 6}}$ (emphasis supplied) Section 62 provides that "[a]ny action or proceeding pending by or against any [corporation] merged may be prosecuted ... as if such merger had not taken place or the corporation resulting from ... such ... merger may be substituted in its place."17 (emphasis supplied)

Noting that the word "suits" was the "dominating term" of section 42 , and that by general usage it refers only to civil litigation, the court reasoned that the words "action" and "proceeding" appearing in the same section and in section 62 must be similarly restricted. ${ }^{18}$ As further buttressing this conclusion, the court also observed that the substitution of parties permitted by section 62 is not characteristic of a criminal prosecution. ${ }^{19}$

On a purely verbal level, while it is true, as the court noted, that the word "suits" generally refers only to civil litigation, ${ }^{20}$ the same cannot unequivocally be said of the words "action"21 and "proceeding."22 The court's unconditional equation of these words in this context, therefore, is not beyond exception. Particularly is this so in view of the fact that section 62 is expressly applicable to "any action or proceeding" (emphasis supplied), and does not even mention "suit." Accordingly, it may be plausibly argued that section 62 saves criminal litigation in dissolutions by merger despite the fact that section 42 may not similarly operate in the winding up of a "truly" dissolved corporation.

Nor do the court's conclusions appear to be irresistibly compelled by policy considerations. ${ }^{23}$ The ancient analogy between corporate and

${ }^{10}$ DEL. REv. CODE C. $65, \S_{42}$ (1935, as amended, 1951).

${ }^{17} I d$. at $\S 62$.

${ }^{18}$ United States v. Line Material Co., 202 F.2d 929 (1953).

${ }^{10}$ Id. at 930 .

${ }^{20} 40$ Words and Phrases 634 et seq. (1940); e.g., Pope v. State, I24 Ga. 80x, 804, 53 S.E. 384,385 (x906); Patterson v. Standard Accident Ins. Co., 178 Mich. 288, 29I, $x_{44}$ N.W. $49 \mathrm{I}, 492$ (x913). But contra, Commonwealth v. Moore, $\mathrm{x}_{43}$ Mass. 136, 137, 9 N.E. 25, 26 (1886); see also Kelliher v. People, 71 Colo. 25, 26, 205 Pac. 274 (x922) ("Suit," when construed with other provisions of the original action of which the section was a part, includes criminal proceedings.).

${ }^{21} 2$ WORDS AND PHRASES 16 et seq. ( 1940 ); "Action" includes criminal prosecutions: People v. Elliott, 172 N.Y. 146, 64 N.E. 837 (1902); Lower v. State, 109 Neb. $590,593, \times 9 \times$ N.W. 674,676 (1923); Mason v. United States, I F.2d 279, 280 (1924). Contra: United States v. Cleveland, 28I Fed. 249, 253 (r922); Commonwealth v. Gallup, 275 Mass. 320, 335, 775 N.E. 718, 725 (193 I); cf. State v. Schomber, 23 Wash. 573, 576, 63 Pac. 221, 222 (xgoo).

22 "Proceeding" includes criminal proceedings: e.g., State v. Nelson, 6 Wash. $2 \mathrm{~d}$. x90, x93, I07 P.2d XI13, III5 (x940). "Criminal proceeding" is common usage, see to Words and PHrases 538 et seq. (1940).

${ }^{23}$ If one assumes arguendo that Line Material was guilty of restraint, monopoliza- 
natural persons would seem to be a frail reed, at best, upon which to rest a conclusion as to whether or not criminal litigation survives corporation dissolution-particularly in cases of dissolution by merger, where the continuity of management, ownership, and properties finds no ready anthropomorphic cognate.

Although it may be contended that the possible unjust enrichment of the successor corporation is mitigated by potential treble damage suits, ${ }^{24}$ which have been held to be maintainable after dissolution or merger, ${ }^{25}$ it is notorious that this remedy is more theoretical than real. ${ }^{20}$ Further, the effectiveness of injunctive relief, ${ }^{27}$ is dubious; ${ }^{28}$ and the difficulties inherent in pursuing individual corporate directors, ${ }^{20}$ whom the anti-trust laws make jointly liable for corporate derelictions, render this alternative of little practical value. ${ }^{30}$

tion, and pricing agreement as charged, its merger, albeit for bona fide purposes, would produce an even greater monopolization as result of the vertical combination. See Buchanan, The Economics of Corporate Enterprise $316 \mathrm{ff}$. (1940). If it were later determined that such a merger violated the anti-trust acts because of the continuance of practices deemed wrongful in the case of the old Line Material Company and/or its combination with the emerging corporation, the federal government must retrace its steps and seek a new indictment against the surviving corporation. The attendant expense, waste, and tactical folly of such duplicity seems apparent. See HaNDLER, A STUDY OF THE CONSTRUCtTon AND ENFORCEMENT OF THE FEDERAL ANTTTRUST Laws 90-92 (TNEC Monograph 38, 1941).

${ }^{24} 38$ STAT. 731 (1914), 15 U.S.C. § 15 (1946).

${ }_{25}$ United States v. Bates Valve Bag Corp., 39 F.2d 162 (D. Del. 1930) 3 see Newmark v. Abeel, 102 F. Supp. 993 (S.D.N.Y. 1952).

${ }^{26}$ See Comment, Fifty Years of Sherman Act Enforcement, 49 YALE L.J. 284 (1939); Donovan and Irvine, Proof of Damages Under the Anti-Trust Law, 88 U. of PA. L. REv. 511 (1940). For an excellent exhaustive treatment recognizing the defects, but showing the place of private actions in anti-trust enforcennent, see Comment, Antitrust Enforcement By Private Parties: Analysis of Developments in the Treble Damage Suit, 6I YALE L.J. 1010 (1952).

${ }^{27} 38$ STAT. 738 (1914), 15 U.S.C. \$ 25 (1946); 38 STAT. 737 (1914), I 5 U.S.C. $\S 26$ (1946). There is dicta to the effect that criminal contempt action under such an injunction may be enforced against a successor corporation, whether the business has been transferred as a means of evading the judgment or for other reasons. United States v. American Optical Co., 97 F. Supp. 71 (N.D. Ill. 195I), citing Walling v. Reuter Co., 321 U.S. 67 r, 674 (1943).

${ }^{28}$ It has been reasoned that the injunction simply declares practices already illegal (and illegal in the criminal sense, United States v. Swift, 188 Fed. 92 (N.D. Ill. x 915 ), and offers no real deterrent until after the injunction is issued. Berge, Remedies Available to the Government Under the Sherman Act, 7 LAW \& CONTEMP. ProB. ro4 (1940). Also see Comments, 6x YaLE L.J. 1010 (1952); 49 YALE L.J. 284 (1939), both cited supra note 26. In dealing with the Line Material situation, this shortcoming in injunctive relief appears multiplied.

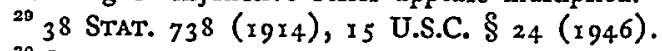

${ }^{30}$ Oppenheim, Cases on Federal Antr-Trust Law 827 (1948), cited at note 5 of Daniel, Enforcement of The Sherman Act By Actions for Treble Damages, 34 
Corporate crimes are sui generis in nature. ${ }^{31}$ Few, if any, of the policy considerations which urge that the crime be permitted to die with the criminal are relevant-especially where the fictitious death is effected in dissolution by merger. Further, in an anti-trust context, the survival of quasi-criminal and unquestionably punitive ${ }^{32}$.treble damage suits reduces to sheerest sophistry the unrelieved abatement of nominally criminal litigation. Although some forward-looking court might have been expected to pierce the veil of dissolution-merger and approach the problem in realistic terms, they have, perhaps understandably, been reluctant to close loopholes in the criminal law, rather leaving this task to the appropriate legislative bodies.

\section{Charles E. Rushing}

VA. L. REV. 901 (1948). It has been pointed out that only after the government has been successful in a criminal action or won an equity decree that private parties can make an effective case. Berge, Some Problems in the Enforcement of the Antitrust Laws, 38 Mich. L. REv. 462, 470 (1940). Also see Comment, 49 YALE L.J. 284 (1939), stupra note 26.

${ }^{31}$ The anti-trust "crime" in action operates similarly to a tort by which defendant corporation is unjustly enriched, a fortiori, enrichment to the emerging corporation in a merger situation. There has been some thought that regardless of individual actions the government should be able to act for the damage done the public; that the public interest is poorly served by leaving to private parties the burden of enforcement is evident. See Berge, supra note 30.

${ }^{32}$ See Southerland, White Collar CRIME 34 (1949). But a contrary result is reached in Vold, Are Threefold Damages Under the Anti-Trust Act Penal or Compensatory?, $38 \mathrm{KY}$. L.J. II7 (1940). 